J. Product. \& Dev., 20(3): 237 - 261(2015)

\title{
EFFECT OF APPLICATION METHODS AND CONCENTATION OF CHITOSAN ON GROWTH, YIELD, TUBER ROOTS QUALITY AND STORABILITY OF SWEET POTATO PLANTS GROWN UNDER SANDY SOIL CONDITIONS
}

\section{E. E. Abou El-Khair}

Potato and Vegetatively Propagated Vegetables Res. Dept., Hort. Res. Inst. Agriculture Research Center, Giza, Egypt.

\section{ABSTRACT:}

This work was carried out during the two successive summer seasons of 2013 and 2014 at a Private Vegetable Farm in El-Khattara distract, Sharkia, Governorate, to investigate the effect of different application methods and concentrations of chitosan ( 0, 0.025, 0.075 and $0.125 \%$ ) on growth, yield, tuber roots quality and storability of sweet potato $\mathrm{cv}$. Buregard grown under sandy soil conditions using drip irrigation system.

Dipping the base of the stem cuttings in chitosan solution before planting + foliar spraying of the plants with chitosan was the best method for increasing dry weight of shoots, N,P and $K$ uptake by shoots, marketable yield and total yield and also, for decreasing weight loss (\%) and decay (\%) in tuber roots during storage period.

Chitosan solution $0.075 \%$ increased growth, average tuber weight, total yield, starch and total sugar in tuber roots, whereas chitosan $0.125 \%$ increased chlorophyll $a$, total $(a+b)$ in leaf tissues, $N, P$ and $K$ uptake by shoots and marketable yield and also recorded minimum values of weight loss and decay (\%) in tuber roots during storage period.

Dipping the base of the stem cuttings in $0.075 \%$ chitosan solution before planting + spraying plants with $0.075 \%$ chitosan solution gave the highest values of vine length, dry weight of shoots/ plant, chlorophyll $a$ and total chlorophyll $(a+b)$ concentration in leaf tissues, average weight of tuber root, total yield, whereas the same treatment gave the lowest values of weight loss percentage and decay (\%) in tuber roots during storage period. On the other hand, the base of 
stem cuttings in $0.125 \%$ chitosan solution before planting + spraying plants with $0.125 \%$ chitosan gave the highest values of N,P and $K$ uptake, marketable yield, starch and total sugar contents in tuber roots.

Conclusively, from the foregoing results of this study, it could be concluded that, under the same conditions, dipping the base of the stem cutting in $0.075 \%$ chitosan solution before planting + spraying plants with $0.075 \%$ chitosan solution three times at 15 days intervals beginning 25 days after transplanting gave the best interaction treatment for increasing plant growth, yield and its components, tuber roots quality and storability of sweet potato plants.

Key words : Sweet potato, chitosan, stem cutting, foliar application, yield and storability.

\section{INTRODUCTION}

Sweet potato (Ipomoea batatas L.) is the seventh most important food crop in the worldwide, after wheat, rice, maize, potato, barley and cassava. The primary importance of sweet potato is in poor regions of the world. It is the fourth most important food crop in developing tropical countries and is grown in most of the tropical and subtropical regions of the earth, where the vine, as well as the roots, are consumed by humans and livestock (Woolfe, 1992). The total cultivated area of sweet potato devoted for production in 2013 in Egypt was 24,750 fed., which produced 320,000 tons with average 12.929 ton/fed. (FAO, 2014).

Chitosan is a natural, low toxic and inexpensive compound that is biodegradable and environmentally friendly with various applications in agriculture. Structurally, chitosan is a straight-chain copolymer composed of D-glucosamine and $\mathrm{N}$-acetyl D-glucosamine being obtained by the partial deacetylation of chitin. It is the most abundant basic biopolymer and its structurally similar to cellulose, which is composed of only one monomer of glucose (De Alvarenga, 2011). Chitosan is derived from chitin, a polysaccharide found in the exoskeleton of shellfish such as shrimp, lobster, and or crabs and cell walls of fungi ( Wojdyla, 2001). Recently, chitosan has been reported to act as a plant growth regulator and considered to elicit the induction of plant defense mechanisms in many plant ( Ben-Shalom et al., 2003; Photchanachai et al., 2006). Moreover, chitosan has been shown to stimulate plant growth (Kim, 2005; Mondal et al., 2012) to posses antioxidants activity ( Xie et al., 2001; Chen et al., 2009), act as antitransparent compound 
that has proved to be effective in many crops ( Khan et al., 2002 ; Karimi et $a l ., 2012$ ) and to improve storability of post harvest fruits and vegetables ( ElGhaouth et al., 1991).

Foliar applications with chitosan resulted in higher vegetative growth and improvement in fruit quality of radish (Farouk et al. 2011). Bittelli et al. (2001) reported that foliar application of chitosan increased biomass production and yield in pepper plants. Abdel-Mawgoud et al. (2010) on strawberry showed that chitosan application improved plant height, number of leaves, fresh and dry weights of the leaves and yield components. Fruit quality in terms of average weight of individual fruits and total sugars showed similar trends. Ghoname et al. (2010) observed that foliar application of chitosan on sweet pepper increased significantly the number of fruits per plant and the mean weight of fruit, as well as quality characteristics such as total acidity, total soluble solid and ascorbic acid content in the fruit. Sheikha and AL-Malki (2011) indicated that application of different concentrations of chitosan enhanced bean shoot and root length, fresh and dry weights of shoots and root and leaf area as well as the level of chlorophyll in leaves. El-Tanahy et al. (2012) reported that the best effect on plant vegetative growth (plant height, number, fresh and dry weights of leaves and shoots), yield and its components (pod length, weight and diameter and number. of seeds and seed yield) and seeds quality (total protein, total carbohydrates $\mathrm{N}, \mathrm{P}$ and $\mathrm{K}$ ) of cowpea were obtained by using the highest concentration of Chitosan (5\%), Mondal et al. (2012) indicated that foliar application of chitosan at 100 or $125 \mathrm{ppm}$ may be used at early growth stage to achieve a maximum fruit yield in okra as compared to 50 or $75 \mathrm{ppm}$. Shehata et al. (2012) showed that foliar application

of chitosan at rates of $4 \mathrm{mlL}^{-1}$ gave the highest vegetative growth, yield and quality of cucumber plants and $\mathrm{P}$ and $\mathrm{K} \%$.

Therefore, the aim of this work was to know the suitable application methods and concentration of chitosan to obtain a high tuber root yield with best quality as well as storability of sweet potato grown in sandy soil.

\section{MATERIALS AND METHODS}

This research was carried out during the two successive summer seasons of 2013 and 2014 under sandy soil conditions using drip irrigation system at a Private Vegetable Farm in El-Khattara distract, Sharkia, Governorate, to investigate the effect of different application methods of 
chitosan (dipping the base of the stem cuttings in chitosan before planting, foliar spraying with chitosan and dipping the base of the stem cuttings in chitosan before planting + foliar application) and different concentrations of chitosan $(0,0.025,0.075$ and $0.125 \%)$ on growth, yield, tuber root quality and storability of sweet potato cv. Buregard.

The physical and chemical properties of experimental soil in the two seasons showed that it was sandy in texture and had 0.08 and $0.09 \%$ organic matter, 8.05 and $8.01 \mathrm{pH}, 1.79$ and $1.74 \mathrm{mmhos} / \mathrm{cm} \mathrm{EC,} 4.81$ and $4.74 \mathrm{ppm}$ available N, 3.39 and 3.48 ppm available $\mathrm{P}$ and 9.67 and $9.41 \mathrm{ppm}$ available $\mathrm{K}$, respectively.

This experiment included 12 treatments, which were the combinations between three application methods (dipping the base of the stem cutting in chitosan before planting, foliar spraying with chitosan and dipping the base of the stem cutting in chitosan before planting + foliar spraying with chitosan) and three concentrations of chitosan $(0.025,0.075$ and $0.125 \%$ as well as control treatment (tap water). These treatments were arranged in a split plot system in a randomized complete block design with three replications. Application methods of chitosan were randomly distributed in the main plot, while the concentration of chitosan were randomly arranged in the sub- plot .

Stem cuttings (about $20 \mathrm{~cm}$ length) were transplanted at $25 \mathrm{~cm}$ apart, on April $15^{\text {th }}$ and $17^{\text {th }}$ in the $1^{\text {st }}$ and $2^{\text {nd }}$ seasons, respectively. Buregard cultivar was used in this experiment .

Chitosan powder (poly - (1,4-B-D-glycopyranosamine ); 2-Amino-2deoxy- ( 1->4)- B-D-glucopyranan ) was prepared by dissolving a proper amount in $5 \%$ acetic acid solution and manufactured by Chengdu Newsun Biochemistry Co., Ltd, China.

Base of the stem cuttings were dipped in different concentrations of chitosan solution or tap water about 4 hrs and hence transplanted in the presence of water, and after that plants were sprayed with the same concentration of chitosan solution or tap water three times at 15 days intervals beginning 25 days after transplanting in both seasons.

The experimental unit area was $12.6 \mathrm{~m}^{2}$. It contains three dripper lines with $6 \mathrm{~m}$ length each and $70 \mathrm{~cm}$ distance between each two dripper lines. One line was used for taking samples to measure the morphological and physiological traits and the other two lines were used for yield determinations. 
Each plot received two 1 solutions of each concentrations using spreading agent in all treatments to improve adherence of the spray to the plant foliage for increasing chitosan absorption by the plants. The untreated plants (check) were sprayed or dipped with tap water and spreading agent. One dripper line was left between each two experimental plots without spraying as a gourd row to avoid the overlapping of spraying salutation.

All treatments received equal amounts of ammonium sulphate $(20.5 \%$ $\mathrm{N})$, calcium superphosphate $\left(15.5 \% \mathrm{P}_{2} \mathrm{O}_{5}\right)$ and potassium sulphate $(48.5 \%$ $\mathrm{K} 2 \mathrm{O}$ ) at a rate of 200,150 and $120 \mathrm{~kg} / \mathrm{fed}$., respectively. One third of $\mathrm{N}$ and $\mathrm{K}_{2} \mathrm{O}$ amount and all amount of $\mathrm{P}_{2} \mathrm{O}_{5}$ were added during soil preparation with FYM which was added at the rate of $20 \mathrm{~m}^{3} / \mathrm{fed}$. The rest of $\mathrm{N}$ and $\mathrm{K}_{2} \mathrm{O}$ were added with irrigation water (as fertigation) at weekly beginning one month after planting. The other conventional practices were applied.

\section{Data recorded}

\section{Plant Growth:}

A random sample of three plants from every experimental unit were randomly taken at 110 days after transplanting in the two growing seasons to measure the plant growth and plant chemical constituents:

a. Vine length (cm) and number of branches/plant,

b. Leaf area/plant: It was calculated according to the formula described by Koller (1972) as follow:

$$
\text { Leaf area }\left(\mathrm{m}^{2}\right)=\frac{\text { Dry weight of leaves }}{\text { Dry weight of disks }}
$$

c. Dry weight of shoot: Leaves and branches of each plant were dried at 70 $\mathrm{C}^{\mathrm{O}}$ till constant weight and then weighed.

\section{Plant Chemical Constituents:}

\section{a. Photosynthetic pigments}

Chlorophyll a and b, as well as carotenoids were determined in the fourth leaf according to the both method described by Wettestein (1957).

\section{b. Uptake of $N, P$ and $K$ in shoots}

Nitrogen, phosphorus and potassium percentages in shoots (leaves and branches) were determined in dry matter according to the both methods described by A.O.A.C. (1995) and N,P and K uptake by shoots were calculated ( $\mathrm{mg} /$ shoot). 


\section{Yield and Its Components:}

At harvest time ( at 150 days from transplanting), all tuber roots of each treatment were classified into two grades (marketable and non-marketable roots), then weighed to determine the total yield per feddan (ton). Marketable tuber roots have a weight about 100 to $250 \mathrm{gm}$, while non-marketable roots have a weight of less than $100 \mathrm{gm}$ or more than $250 \mathrm{gm}$. In addition, average tuber root weight were calculated.

\section{Tuber root quality at harvest time:}

a. Starch content (\%): It was determined in dried tuber roots according to the both methods described by A.O.A.C. (1995).

c. Total sugars (\%): It was determined according to the both method described by Forsee (1938).

d. Total soluble solids (T.S.S. \%) : It was determined in flesh juice of tuber roots by Carle Zeis refractometer.

e. Carotenoids content: It was determined in fresh tuber root tissues according to the both method reported by A.O.A.C. (1995).

\section{Storability:}

At harvest time, the tuber roots from every experimental unit were translocated to shady place in the same day for curing, and placed for one week. Samples of uniform cured tuber roots $(5 \mathrm{~kg})$ from every experimental unit were put in palm crates and stored at normal room temperature and relative humidity. The storage zero time was September $25^{\text {th }}$, while the end time of storage was January $25^{\text {th }}$ in both seasons. The average room temperature and relative humidity (RH\%) during storage months are presented in Table (A).

Table (A): The average room temperature $\left({ }^{\circ} \mathrm{C}\right)$ and relative humidity (\%) during storage months

\begin{tabular}{|lcccc|}
\hline Month & \multicolumn{2}{c}{ Temperature $\left({ }^{\mathbf{}} \mathbf{C}\right)$} & \multicolumn{2}{c|}{ Relative humidity (\%) } \\
\cline { 2 - 5 } & $\mathbf{2 0 1 3 / 2 0 1 4}$ & $\mathbf{2 0 1 4 / 2 0 1 5}$ & $\mathbf{2 0 1 3 / 2 0 1 4}$ & $\mathbf{2 0 1 4 / 2 0 1 5}$ \\
\hline Sep. & 31.2 & 32.5 & 71 & 72 \\
Oct. & 28.5 & 30.1 & 73 & 74 \\
Nov. & 25.4 & 26.3 & 76 & 80 \\
Dec. & 20.6 & 20.6 & 81 & 84 \\
Jan. & 17.1 & 15.7 & 83 & 82 \\
\hline
\end{tabular}


The following data were monthly recorded in both seasons:

a. Weight loss (\%): Tuber roots of each treatment were weighed at 30 days by intervals, then the cumulative weight loss percentage was calculated.

b. Decay (\%): Decayed tuber roots were removed and weighed. They included all spoiled tuber roots resulting from fungal or bacterial infections. The percentage of decayed tuber roots was calculated in relation to the total initial weight of stored tuber roots.

\section{Statistical Analysis:}

Recorded data were subjected to the statistical analysis of variance according to Snedecor and Cochran (1980), and means separation were done according to LSD at $5 \%$ level.

\section{RESULTS AND DISCUSSION}

\section{Plant Growth}

Respecting the effect of application methods of chitosan on growth of sweet potato plants grown in sandy soil, presented data in Table 1, show that dipping the base of the stem cuttings (DSC) in chitosan solution before planting + foliar spraying (FS) of plants with chitosan solution significantly increased vine length, number of branches/ plant, leaf area/plant and dry weight of shoots/ plant in both seasons compared with dipping the base of the stem cuttings (DSC) or spraying of plant (FS) with chitosan only. The increases in dry weight of shoots/ plant were about 6.82 and $5.62 \%$ for foliar application and 27.04 and $21.70 \%$ for dipping+foliar application over the dipping application in the $1^{\text {st }}$ and $2^{\text {nd }}$ seasons, respectively. Dipping the base of the stem cuttings (DSC) + foliar spraying (FS) of the plants with chitosan increased vine length. This may be due to that dipping of cuttings in chitosan solution improved rooting of cuttings and number of internodes (Gornik et al., 2008).

Concerning the effect of chitosan concentration, the obtained results in Table 1, illustrate that chitosan at different concentrations significantly increased plant growth comparing to control treatment (tap water). Vine length, number of branches/ plant, leaf area and dry weight of shoots/ plant increased with increasing chitosan concentration up to $0.125 \%$ with no significant differences between $0.075 \%$ and $0.125 \%$ chitosan. This means 
E. ABOU EL-KHAIR 
that $0.075 \%$ chitosan was found to be the most effective on vine length, number of branches / plant, leaf area and dry weight of shoots/ plant. The increases in dry weight of shoots/ plant were about 26.66 and $14.83 \%$ for $0.025 \%$ chitosan concentration, 40.25 and $22.13 \%$ for $0.075 \%$ chitosan and 47.01 and $36.91 \%$ for $0.125 \%$ chitosan over the control (tap water) in the $1^{\text {st }}$ and $2^{\text {nd }}$ seasons, respectively.

As for the effect of the interaction between application methods and concentrations of chitosan, data in Table 1 indicate that dipping the base of the stem cuttings (DSC) in $0.125 \%$ chitosan before planting + foliar spraying (FS) of plants with $0.125 \%$ chitosan significantly increased vine length and dry weight of shoots in both seasons, leaf area in the $1^{\text {st }}$ season and number of branches/ plant in the $2^{\text {nd }}$ season with no significant differences with dipping the base of the stem cuttings in $0.075 \%$ chitosan before planting + foliar spraying with $0.075 \%$ chitosan in the $1^{\text {st }}$ season only. The base of the stem cutting in $0.075 \%$ chitosan solution before planting+ foliar spraying with $0.075 \%$ chitosan increased vine length and dry weight of shoots/ plant. In general, application methods of chitosan (dipping the base of the stem cuttings before planting, foliar spraying with chitosan and dipping+ foliar) with different used concentrations of chitosan increased growth of sweet potato plants compared to the same application methods with tap water (control), and also plant growth increased with increasing chitosan concentration up to $0.125 \%$ under the same application methods.

Concerning the positive effect of chitosan on plant growth, it had molecular signals that served as plant growth promotes (Hadwiger et al., 2002) and a role in increasing key enzymes activities of nitrogen metabolism ( nitrate reductease, glutamine synthetase and protease), in addition, chitosan improved the transportation of nitrogen in the functional leaves which enhanced plant growth and development (Qiang et al., 2007; Mondal et al., 2012) as well as, the greater availability of amino compounds released from it ( Chibu and Shibayama, 2001).

Furthermore, foliar application of chitosan increased the net photosynthetic rates of soybean (Khan et al., 2002), it stimulates plant immune systems, plant growth and plant production, also protects plants against attack by microorganism ( Hadwiger et al., 2002 and Nge et al., 2006) and increases the availability and uptake of water and essential nutrients through adjusting cell osmotic pressure and reducing the accumulation antioxidants and enzyme activities ( Guan et al., 2009). 
These results were in agreement with those obtained by Bittelli et al. (2001) on pepper plants, Abdel-Mawgoud et al. (2010) on strawberry and Ghoname et al. (2010) on sweet pepper and Sheikha and AL-Malki (2011) on bean. They all indicated that application of different concentrations of chitosan enhanced shoot and root length, fresh and dry weights of shoots and root as well as leaf area/ plant.

\section{Photosynthetic pigments:}

Application methods of chitosan (DSC, FS and DSC+ FS) reflected a significant effect on chlorophyll (a) and total chlorophyll $(a+b)$ concentrations in the leaf tissues of sweet potato plants, but did not reflect any significant effect on chlorophyll $b$ and carotenoides in both seasons (Table 2). DSC in chitosan solution before planting + FS of plants with chitosan solution increased chlorophyll a and total chlorophyll in leaf tissues.

Chlorophyll a, b and total chlorophyll $(\mathrm{a}+\mathrm{b})$ as well as carotenoides concentrations in the leaf tissues of sweet potato plants significantly increased with increasing chitosan concentration up to $0.125 \%$, except carotenoides in the $1^{\text {st }}$ season ( Table 2).

The DSC in chitosan $0.125 \%+$ FS with chitosan $0.125 \%$ increased the concentration of chlorophyll a and total chlorophyll $(\mathrm{a}+\mathrm{b})$ in leaf tissues with no significant differences with DSC in chitosan $0.075 \%+$ FS chitosan $0.075 \%$ ( Table 2). This means that DSC in chitosan $0.075 \%+$ FS with chitosan solution $0.075 \%$ increased chlorophyll a and total chlorophyll $(a+b)$ concentrations in leaf tissues.

Chitosan increased photosynthetic pigments by enhancing endogenous levels of cytokinins, which stimulate chlorophyll synthesis (Chibu and Shiayama (2001). These results are in agreement with the results obtained by Farouk et al. (2008 and 2011) on cucumber and radish, respectively and Sheikha and Al-Malki (2011) on bean.

\section{3. $N, P$ and $K$ uptake:}

Concerning the effect of application methods on N,P and K uptake, data in Table 3, show that DSC in chitosan solution + FS with chitosan solution before planting significantly increased N,P and K uptake by shoots compared to DSC or FS methods each alone.

Respecting the effect of chitosan concentration, the obtained results in Table 3 indicate that $\mathrm{N}, \mathrm{P}$ and $\mathrm{K}$ uptake by sweet potato shoots significantly increased with increasing chitosan concentration up to $0.125 \%$ in both seasons. 
E. ABOU EL-KHAIR 
With respect to the interaction between application methods and chitosan concentrations, data in Table 3 illustrate that DSC in $0.125 \%$ chitosan solution before planting $+\mathrm{FS}$ with $0.125 \%$ chitosan solution significantly increased N,P and $\mathrm{K}$ uptake in both seasons. This means that DSC in $0.125 \%+$ chitosan solution FS with $0.125 \%$ chitosan solution increased N, P and K uptake by shoots. The stimulative effect of DSC in $0.125 \%$ chitosan + FS of plants with $0.125 \%$ chitosan concentration on N,P and $\mathrm{K}$ uptake may be due to that this interaction treatment increased dry weight of shoots/ plant (Table 1).

The increment in $\mathrm{N}$ uptake by shoots may be brought about by the amino components in chitosan and or higher ability of the plant to absorb $\mathrm{N}$ from the soil when chitosan was degraded. Also the higher uptake of $\mathrm{K}$ explains the higher quality of the fruits due to the presence of $\mathrm{K}$ which acts on photosynthate translocation from the leaves to the storage organs (El-Tanahy et al., 2012).

\section{Yield and Its components:}

Respecting the effect of application methods on yield and its components, the obtained results in Table 4, indicate that application methods of chitosan had significant effect on marketable yield and total yield of sweet potato plants in both seasons, but had no significant effect on average weight of tuber root and unmarketable yield. DSC in chitosan solution before planting + FS with chitosan solution significantly increased marketable yield and total yield/ fed. in both seasons compared to DSC or FS methods each alone.

The increases in total yield were about $1 \%$ and $1.7 \%$ for FS and 9.8 and $7.8 \%$ for DSC+ FS over DSC in the $1^{\text {st }}$ and $2^{\text {nd }}$ seasons, respectively. The stimulative effect of DSC + FS on total yield may be due to that dipping+ foliar application increased plant growth (Table 1) chlorophyll a and total chlorophyll (Table 2) and N,P and K uptake (Table 3).

Regarding the effect of chitosan concentration, the obtained data in Table 4 show that average weight of tuber root, marketable yield and total yield increased with increasing chitosan concentration up to $0.125 \%$, whereas unmarketable yield decreased with increasing chitosan concentration up to $0.125 \%$. Chitosan solution at $0.125 \%$ increased average weight of tuber root, marketable yield and total yield with no significant differences between $0.075 \%$ and $0.125 \%$ chitosan with respect to average weight of tuber root and total yield.

From the foregoing results, it could be concluded that, $0.075 \%$ chitosan was the best treatment for increasing average weight of tuber root and total 
E. ABOU EL-KHAIR 
yield. Whereas $0.125 \%$ chitosan was the best treatment for increasing marketable yield and decreasing unmarketable yield. These results may be due to that $0.125 \%$ chitosan increased plant growth (Table 1), photosynthetic pigments in leaves (Table 2) and $\mathrm{N}, \mathrm{P}$ and $\mathrm{K}$ uptake (Table 3) as well as average weight of tuber roots ( Table 4).

The increases in total yield were about 5.9 and $11.3 \%$ for chitosan $0.075 \%$ and 21.5 and $18.5 \%$ for chitosan $0.125 \%$ over the control (tap water) in the $1^{\text {st }}$ and $2^{\text {nd }}$ seasons, respectively.

The interaction between application methods and chitosan concentration had significant effect on yield and its components of sweet potato (Table 4). DSC in $0.125 \%$ chitosan before planting + FS with 0.125 $\%$ chitosan increased average weight of tuber root, marketable yield and total yield with no significant differences with DSC in $0.075 \%$ chitosan before planting + FS of $0.075 \%$ chitosan with respect to average weight of tuber root and total yield. DSC in $0.125 \%$ chitosan before planting + FS of $0.125 \%$ chitosan decreased unmarketable yield.

In general, application methods (DSC, FS and DSC+ FS) with chitosan at different concentrations $(0.025,0.075$ and $0.125 \%)$ were the best treatments for increasing total yield compared to the same application methods with tap water (control) and also total yield increased with increasing chitosan concentration up to $0.125 \%$, under different used application methods.

From the foregoing results, it could be concluded that, DSC in chitosan $0.075 \%$ before planting + FS of chitosan $0.075 \%$ increased average weight of tuber roots and total yield, whereas DSC in chitosan $0.125 \%+$ FS with chitosan at $0.125 \%$ increased marketable yield and decreased unmarketable yield.

The increase in yield from chitosan treated plants is a result of protecting plants against microorganisms (Nge et al., 2006), stimulation of roots, shoots, leaves, chlorophyll content and photosynthetic rate ( Khan et al., 2002; Gornik et al., 2008) which led to the increment in the vigor growth followed by active translocation of photoassimilates from source to sink tissues and hence increased yield.

These results agree with those reported by El-Tantawy (2009) on tomato, Abdel-Mawgoud et al. (2010) on strawberry, Ghoname et al. (2010) on sweet pepper, El-Tanahy et al. (2012) and Farouk and Ramadan (2012) on cowpea, Fawzy et al. (2012) on garlic, Shehata et al. (2012) on cucumber, Mondal et al. (2012) on okra and El-Miniawy et al. (2013) on strawberry. 


\section{Tuber root quality:}

It is clear that application methods of chitosan had significant effect on starch ( $\%$ ) in both seasons and total sugars in the $2^{\text {nd }}$ season, but had no significant effect on TSS (\%) and carotene content in both seasons ( Table 5) . DSC in chitosan before planting + FS with chitosan increased starch (\%) in tuber roots.

Chitosan at different concentrations reflected a significant effect on starch $(\%)$ and total sugars $(\%)$ in both seasons and TSS $(\%)$ in the $1^{\text {st }}$ season, whereas did not reflect any significant effect on carotene content in both seasons. Starch and total sugars (\%) in sweet potato tuber roots increased with increasing chitosan concentration up to $0.125 \%$ with no significant differences with chitosan $0.075 \%$ ( Table 5).

The interaction between application methods and chitosan concentrations had significant effect on starch (\%) and total sugars, but had no significant effect on TSS \% and carotene contents in tuber roots (Table 5). DSC in chitosan $0.125 \%$ before planting $\%+$ FS with chitosan $0.125 \%$ increased starch $(\%)$ and total sugars content in tuber roots.

The favorable effect of chitosan on chemical composition of tuber roots might be referred to greater availability of amino compounds released from it ( Chibu and Shibayama, 2001) and increases the availability and uptake of water and essential nutrients ( Guan et al., 2009). In addition, chitosan also contains high amount of calcium minerals where they aid structural rigidity (BoBelmann et al., 2007) and the hydroxylated amino groups present on chitosan oligomers make them extremely effective scavengers of hydroxyl radicals, hydrogen peroxide and anion superoxide (Xie et al., 2001 and Sun et al., 2008). Moreover, chitosan increased photosynthetic rate (Khan et al., 2002) and therefore, increase the accumulation of photosynthetic output compound in tuber roots.

These results were in agreement with those obtained from AbdelMawgoud et al. (2010) on strawberry and Ghoname et al. (2010) on sweet pepper.

\section{Storability (weight loss and decay \%):}

Respecting the effect of application methods, data in Tables 6 and 7, show that, at 120 days of storage period, DSC in chitosan solution before planting+ FS with chitosan solution decreased weight loss and decay percentages in tuber roots during storage period. Weight loss and decay 
E. ABOU EL-KHAIR 
percentages gradually increased with increasing storage period up to 120 days.

Chitosan at different concentrations (0.025, 0.075 and $0.125 \%$ ) decreased weight loss and decay percentages in tuber roots compared to control (tap water) and weight loss percentage decreased with increasing chitosan concentration up to $0.125 \%$. This means that, at 120 days form storage, chitosan $0.125 \%$ recorded the minimum values of weight loss percentage and decay \% ( Tables 6 and 7).

DSC in 0.075 or $0.125 \%$ chitosan before planting + FS with 0.075 or $0.125 \%$ chitosan recorded the minimum values of weight loss percentage and decay (\%) in tuber roots during storage period ( Tables 6 and 7). Decay (\%) recorded the maximum values at 120 days from storage. This may be due to that decrease average temperature and increase relative humidity during Dec. and Jan. months (Table A).

Chitosan, it has been shown that chitosan seemed to have anti-fungal activity against a wide range of fungi ( El-Ghaouth et al., 1991) and induced the expression of a variety of genes involved in plant defense responses ( Loschke et al. , 1983; Walker-Simmons et al., 1983). Moreover, chitosan can reduce pathogenesis infection through direct toxicity or chelation of nutrients and minerals from pathogens and also from physical barriers around the penetration sites of pathogens, preventing them from spreading to healthy tissues ( El-Hadrami et al., 2010).

In addition, chitosan have shown a great potential as natural biodegradable substances which have anti-microbial activities and could effectively inhibit postharvest disease of fruits by direct inhibition on spore germination, germ tube elongation and mycelia growth of phytopathogens and indirect inducement of defenses related enzyme such as phenylalanine ammonialyase (Zhang et al., 2011).

Conclusively, it could be concluded that, under the same conditions, dipping the base of the stem cutting in $0.075 \%$ chitosan solution before planting + spraying plants with $0.075 \%$ chitosan solution gave the best interaction treatment for increasing plant growth, yield and its components, tuber roots quality and storability of sweet potato plants. 


\section{REFERENCES}

Abdel-Mawgoud A.M.R., A.S. Tantawy, M.A. El-Nemr and Y.N. Sassine (2010). Growth and yield responses of strawberry plants to chitosan application. Euro. J. Sci. Res., 39 (1):161-168.

A.O.A.C. Association of Official Agricultural Chemists (1995). Official Systems Of Analysis. 17 ${ }^{\text {th }}$. ed. A.O.A.C., Wash., D.C

Ben-Shalom, N., R. Ardi, R. Pinto, C. Aki and E. Fallik. (2003). Controlling gray mould caused by Botrytis cinerea in cucumber plants by means of chitosan. Crop Protection, 22: 285-290.

Bittelli, M., M. Flury, G.S. Campbell and E.J. Nichols (2001). Reduction of transpiration through foliar application of chitosan. Agricultural and Forest Meteorology, 107(3): 167-175.

BoBelmann, F., P. Romano, H. Fabritius, D. Raabe and M. Epple (2007). The composition of the exoskeleton of two crustacean. The American lobster Hormarus americamus and the edible crab Cancer pagurus. Thermochimica Acta, 463: 65-68.

Chen, W.G., X. Liu and H.X. Chen (2009). Preparation of modified chitosan with quaternary ammonium salt. Textile Bioengineering and Informatics Symposium Proceedings, 1:226-230.

Chibu, H. and H. Shibayama (2001). Effect of chitosan application on the growth of several crops. in :Uragami, T., K. Kurita and T. Fukamizo ( Eds), Chitin And Chitosan In Life Science. Yamaguchi, pp: 235-239.

De Alvarenga, E.S. (2011). Characterization and properties of chitosan, Biotechnology of Biopolymers, Available from: http://www. intechopen.com/books/ biotechnology ofbiopolymers / characterization and-properties-of-chitosan.

EI-Ghaouth, A. ; J. Arul; R. Ponnampalam and M. Boulet (1991). Chitosan coating effect on storability and quality of fresh strawberries. J. Food Sci., 56(6): 1618-1620.

El-Hadrami, A.; L.R. Adam; I. El-Hadrami and F. Daayf (2010). Chitosan in plant protection. Mar. Drugs, 8: 968-987.

El-Miniawy, S.M., M.E. Ragab, S.M. Youssef and A.A. Metwall (2013). Response of strawberry plants to foliar spraying of chitosan. Res. J. Agric. Bio. Sci., 9(6): 366-372. 
El-Tanahy, A.M.M., A.R. Mahmoud, M. M. Abde-Mouty and A. H. Ali (2012). Effect of chitosan doses and nitrogen sources on the growth, yield and seed quality of cowpea. Aust. J. Basic and Appl. Sci., 6(4): 115-121.

El-Tantawy, E.M. (2009). Behavior of tomato plants as affected by spraying with chitosan and aminofort as natural stimulator substances under application of soil organic amendments. Pakistan J. Biol. Sci., 12: 1164-1173.

FAO (2014). Food and Agricultural Orgnization of United Nations, Available at http://www faostat.fao.org.

Farouk, S.; A.A. Mosa; A.A. Taha; Ibrahim Heba M. and A.M. ElGahmery (2011). Protective effect of humic acid and chitosan on radish (Raphanus sativus L. var. sativus) plants subjected to cadmium stress. Journal of Stress Physiology \& Biochemistry, 7(2):99-116.

Farouk, S. and A. A. Ramadan (2012). Improving growth and yield of cowpea by foliar application of chitosan under water stress. Egyptian J. of Biol. , 14: 14-26.

Farouk, S., K.M. Ghoneem and A.A. Ali (2008). Induction and expression of systematic resistance to downy mildew disease in cucumber plant by elicitors. Egyptian Journal of Phytopathology, 1-2: 95-111.

Fawzy, Z.F.,Z.S., El-Shal, Li Yunsheng, Ouyang Zhu and Omaima M. Sawan (2012). Response of garlic (Allium sativum L.) plants to foliar spraying of some bio-stimulants under sandy soil condition. J. Appli. Sci. Res., 8(2): 770-776.

Forsee, W. T., Jr.(1938). Determination of sugar in plant materials A photometeric method. Indus. Eng. Chem. Anal. Ed., 10:411-418.

Ghoname, A. A. , M.A. EL-Nemr, A.M.R. Abdel-Mawgoud and W.A. El-Tohamy (2010). Enhancement of sweet pepper crop growth and production by application of biological, organic and nutritional solutions. Res. J. of Agric. and Biol. Sci., 6 (7): 349-355.

Gornik K., M. Grzesik and B.R. Duda (2008). The effect of chitosan on rooting of gravevine cuttings and on subsequent plant growth under drought and temperature stress. J. Fruit Ornamental Plant Res., 16: 333-343.

Guan, Y. J. Hu, X. Wang and C. Shao (2009). Seed priming with chitosan improves mize germination and seedling growth in relation to physiological changes under low temperature stress. J. Zhejiang Univ. Sci. B., 10(6):427-433. 
Hadwiger, L.A.; S.J. Klosterman and J.J. Choi (2002). The mode of action of chitosan and its oligomers in inducing plant promoters and developing disease resistance in plant. In: Suchiva, K. S. Chandrkrachang, P. Methacanon and M.G. Peter (Eds.) Advances in Chitin Science. Bangkok, pp: 452-457.

Karimi, S.; H. Abbaspour; J. M. Sinaki and H. Makarian (2012). Effects of water deficit and chitosan spraying on osmotic adjustment and soluble protein of cultivars castor bean ( Ricinus communis L. ). J. Stress Physiol. Bio., 8: 160-169.

Khan, M.H.; K.L.B. Singha and S.K. Panda (2002). Changes in antioxidants levels in Oryza sativa L. roots subjected to $\mathrm{NaCl}$ salinity stress. Acta Physiol. Plantarum, 24(2): 145-148.

Kim, H. J. (2005). Characterization of bioactive compound in essential oils, fermented anchovy sauce and edible plants and induction of phytochemical from edible plants using methyl jasmonate ( MeJA) and chitosan. Ph.D. Thesis, Clemson University, USA, 178 pp.

Koller, H.R. (1972). Leaf area - Leaf weight relationship in the soybean canopy. Crop Sci., 12: 180-183.

Loschke, D.C., L.A. Hadwiger, and W. Wagoner (1983). Comparison of mRNA populations coding for phenylalanine ammonialyase and other peptides from pea tissue treated with biotic and a biotic phytoalexin inducers. Physiol. Plant Pathol., 23(1):163-173.

Mondal, M.M.A., M.A. Malek, A.B. Puteh, M.R. Ismail, M. Shrafuzzaman and L. Naher (2012). Effect of foliar application of chitosan on growth and yield of okra. Aust. J. of Crop Sci., 6 (5): 918-921.

Nge, K.L.; N. Nwe.; S. Chandrkrachang and W.F. Stevens (2006) Chitosan as a growth stimulator in orchid tissue culture. Plant Science, 170 :1185-1190.

Photchanachai, S. J. Singkaew and J. Thamthong (2006). Effect of chitosan seed treatment on Colletotrichum sp. and seedling growth of chilli cv. $J$. Inida. Acta Hort., 712:585-590.

Qiang, L. , P. Jian-wele, R. Xiang-min , X. Gul-xian and Hong-mei, Z. (2007). Effect of carboxymethyl chitosan on nitrogen metabolism of rice. Plant Nutrition and Fertilizer Science, 13(4):597.

Shehata, S. A.; F. F .Zakaria and H. R. El-Ramady (2012). Response of cucumber plants to foliar application of chitosan and yeast under greenhouse conditions. Aust. J. of Basic and Appl. Sci., 6 (4): 63-71. 
Sheikha, S.A. and F. M. Al-Malki (2011). Growth and chlorophyll responses of bean plants to chitosan applications. European Journal of Scientific Research, 50 (1): 124-134.

Snedecor, G.W. and W.G. Cochran (1980). Statistical Methods. $7^{\text {th }}$ ed., Iowa State Univ., Press, Ames., Iowa, U.S.A.

Sun, T.; Q. Yao; D. Zhou and F. Mao. (2008). Antioxidants activity of Ncarboxymethyl chitosan oligosaccharides. Bioorg. Med. Chem. Lett., 18:5774-5776.

Walker-Simmons; M. L.A. Hadwiger and C.A. Ryan (1983). Chitosan and peptic polysaccharides both induce the accumulation of the antifungal phytoalexin pisatin in pea pods and antinutrient proteinase inhibitors in tomato leaves. Biochem. Biophys. Res. Commun., 110 (1):194-199.

Wettestein, D. (1957). Chlorophyll. Lethale under Submikroskopische Formwechsel der Plastiden. Exp. Cell Reso, 12: 427-506.

Wojdyla, A.T. (2001). Chitosan in the control of rose disease-6 year trials. Acad. Sci. Biol. Sci., 49: 233-252.

Woolfe, J. A. (1992). Sweet Potato: an untapped food resource. New York: Cambridge University Press.

Xie, W.; P. Xu and Q. Liu. (2001). Antioxidant activity of water soluble chitosan derivatives. Bioorg. Med. Chem. Lett., 11: 1699-1701.

Zhang, H.; L.I. Renping and L. Weimin (2011). Effects of chitin and its derivative chitosan on postharvest decay of fruits: A Review: Int. J. Mol. Sci., 12(2): 917-934.
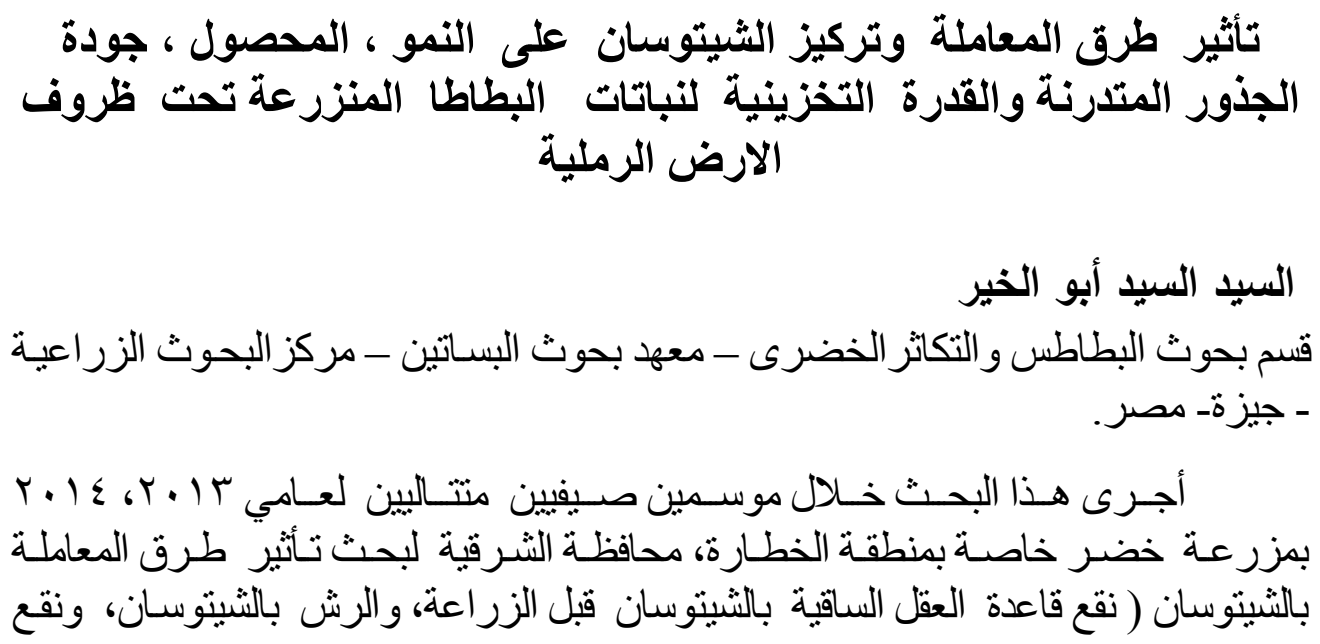


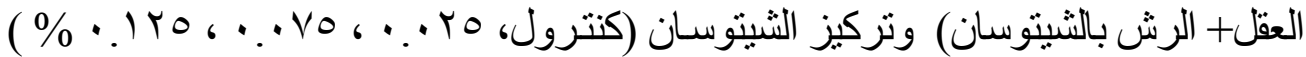

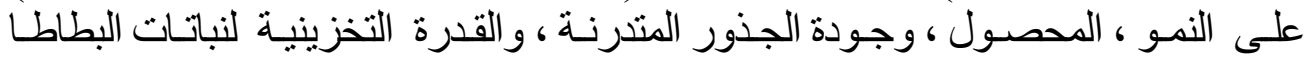
صنف بيوريجارد المنزرع تحت ظروف الأرض الرول الرملية ونظام الرى بالتنقيط.

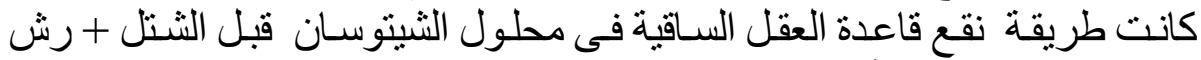

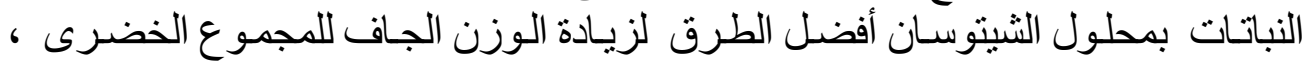

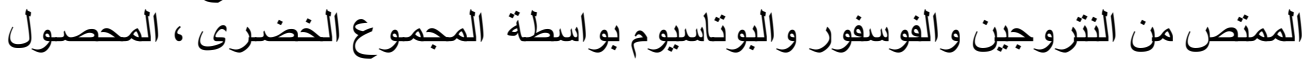

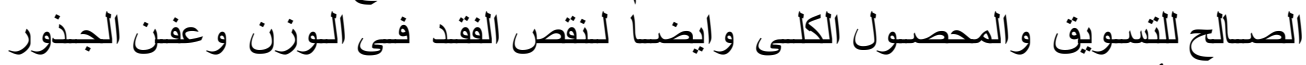

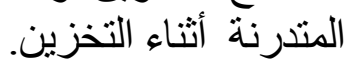

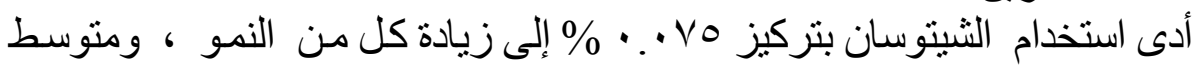

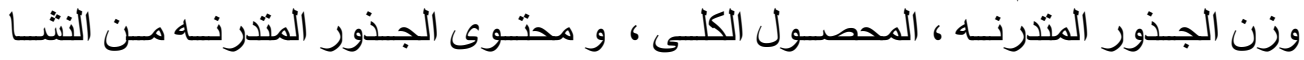

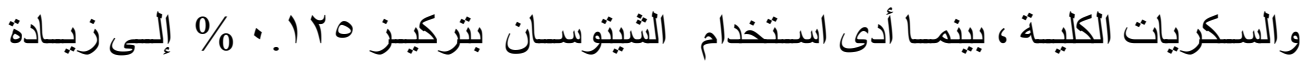

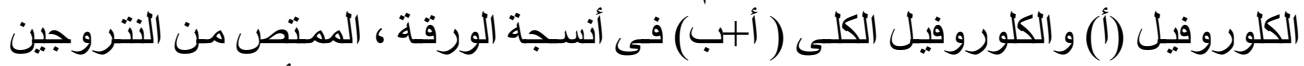

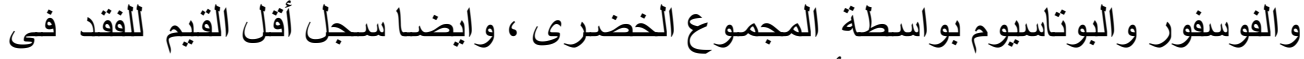
الوزن وعفن الجذور المتدرنة أثناء التخزين.

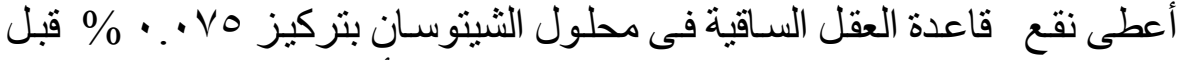

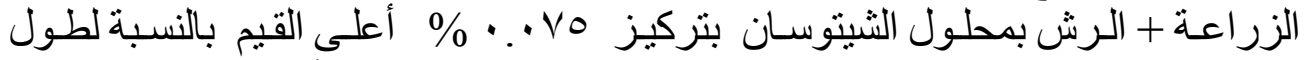

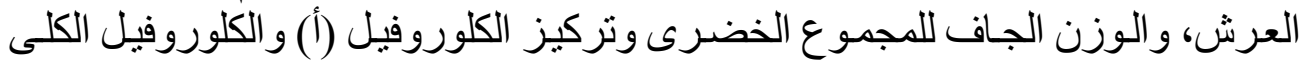

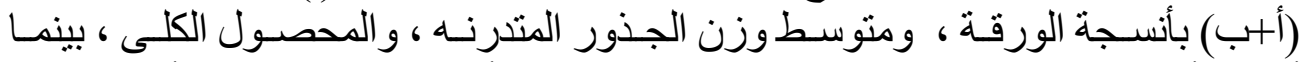

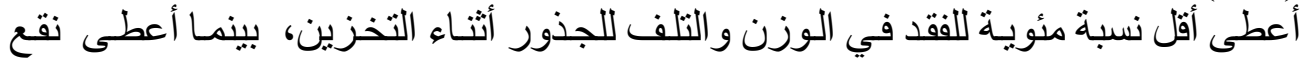

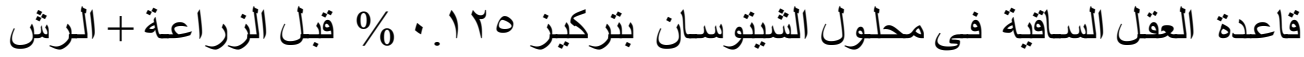

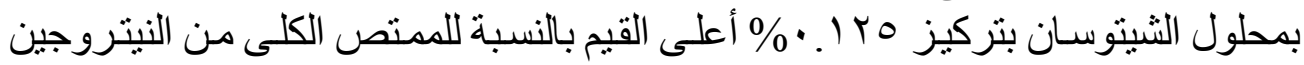

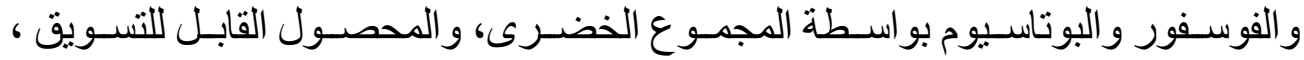
ومحتوى الجذور المتدرنه من النشاو السكريات الكلية.

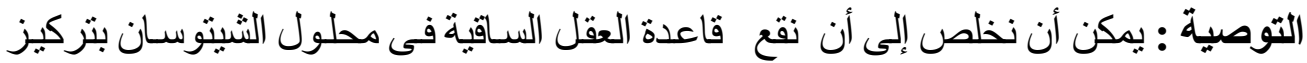

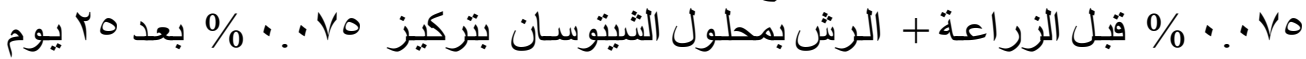

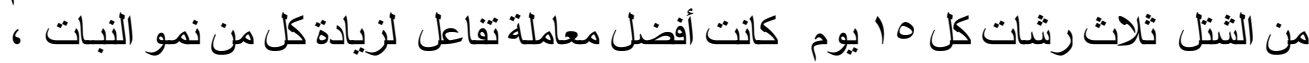

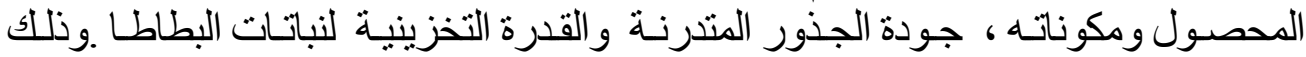

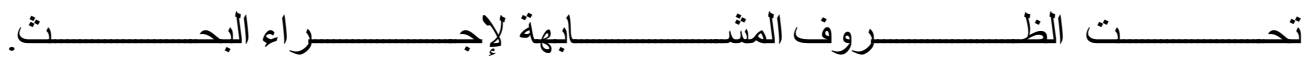



J. Product. \& Dev., 20(3): $237-261(2015)$ 